\section{Gladbok for den som vil forandring}

Tyrdal S.

Endringsglede

Forandring på egne premisser. 271 s, ill. Asker: Humorologisk forlag, 2008. Pris NOK 345

ISBN 978-82-997317-2-0

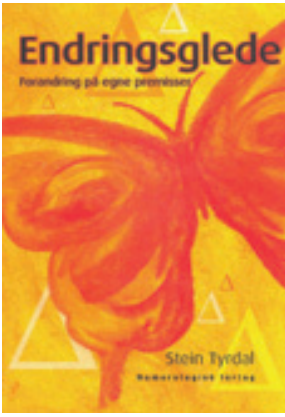

Hvorfor er det så vanskelig å se på forandringer som noe positivt? Forfatteren, som er ortoped, forsøker her å gi svar på dette ved hjelp av 75 suksesshistorier, 80 sider «coachende» spørsmål, inspirerende fakta, stimulerende tips og en modell for personlige og organisatoriske endringer. Han utfordrer også leserne til en test på hvor gode de er til å tåle endring.

Målgruppen er definert ut fra utsagnet «boken for superledere som sørger for at medarbeidere påvirker og leder seg selv». Det er i hvert fall en ambisiøs tilnærming. $\mathrm{Vi}$ har alle behov for å forandre oss i et samfunn som stiller større krav til raskere og mer gjennomgripende endring enn noen gang tidligere.

Det hele er bygd opp rundt sitater og personlige historier - utgangspunkt for drøfting av oppgaver, som presenteres etter hvert avsnitt. Det blir ganske mange oppgaver, og forfatteren mener at materialet egner seg ypperlig for refleksjon i grupper. Med alle de kritiske spørsmålene som stilles til leseren er jeg i tvil om at gruppearbeid er det man først bør ty til.

Det er ingen tvil om at humor, glede og positiv innstilling til endring er svært viktig. Dette er bokens styrke. Men med alle oppgavene og gjennomgang av de seks faser som forfatteren har i sitt endringshjul, er jeg litt i tvil om han vil nå ut til dem som virkelig trenger det - de som ikke vil endre seg eller har begrenset humoristisk sans og selvironi.

Endringshjulets seks faser er greit beskrevet. Kanskje ville jeg ha lagt mer vekt på fase 6: stabil, vedvarende endring. Dette er vel noe av det vanskeligste med alle endringer - stadig å være i forandring, å lete etter forbedring og forandring hos en selv, i ens organisasjon og gjerne også i privatlivet.

Det er ingen tvil om at dette er en «gladbok». Den henvender seg til ledere i alle bransjer. Utfordringen blir å få både ledere og medarbeidere til virkelig å være opptatt av endringsglede. En ugleillustrasjon er gjennomgangfigur - ikke tilfeldig valgt. Jeg savner referanse til Nils Arne Eggens Godfoten, siden Eggen og Tyrdal etter min mening har mange gode egenskaper til felles.
Endringsglede har mye fin humor og tvinger leseren til refleksjon over seg selv. Jeg tror først og fremst den vil appellere til ledere, som kan plukke opp mange nyttige ideer til bruk i endringsarbeid.

\section{Knut E. Schrøder}

Universitetssykehuset Nord-Norge Tromsø

\section{Endringskynisme} Amundsen 0 , Kongsvik $T$.
Endringskynisme

197 s, ill. Oslo: Gyldendals Akademisk, 2008. Pris NOK 289

ISBN 978-82-05-38402-6

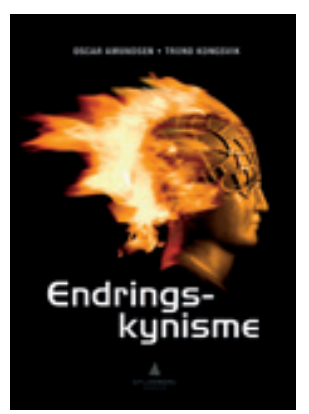

«Endringskynisme» er et nytt ord som intuitivt gir mening. Det defineres som en innstilling der medarbeiderne opplever at endringene er forstyrrende, ikke medfører bedring og tar oppmerksomheten vekk fra kjerneoppgavene. Denne utgivelsen er for den som søker teoretisk kunnskap om endringer og medvirkning i organisasjoner. Den skiller seg fra mange andre ledelsesbøker i ved at man forsøker å se organisasjonsendringene nedenfra og opp, ikke omvendt.

Man forsøker å forklare hva endringskynisme er, hvordan den oppstår og ikke minst hva som kan gjøres for å forhindre fenomenet. Forfatterne har begge doktorgrad på området og troverdighet gjennom den omfattende datainnsamling de har gjort i tre norske bedrifter.

I første del forklares en del begreper knyttet til organisasjon og endring, deretter følger en del eksempler fra praksis. Videre presenteres modeller som kan forklare endringskynisme. Siste del er viet spørsmålet om hvordan man kan unngå fenomenet ved hjelp av medvirkning eller «empowerment», som det heter på engelsk og som heller ikke forfatterne har greid å finne et godt norsk begrep for.

Endringskynisme vekker stor grad av gjenkjennelse. Fenomener som «endring for endringens skyld», «resirkulering av ideer», «praksisfjerne løsninger» og «pseudomedvirkning» er alle kjente.

Man kjenner seg igjen i det meste som beskrives og undrer seg over hvorfor ikke flere ledere og organisasjoner lærer av sine feil? At ikke alle endringer er positive, at det legges for lite vekt på motivasjon for endring. At den beste motivasjonen er en krise der flertallet skjønner at man må gjøre noe annerledes for å komme ut av den. Forfatterne skriver at sett fra et ledelsesperspektiv betraktes motstand som noe negativt. De foreslår at det noen ganger kan være en dårlig idé å gjennomføre endringer. Det mest aktuelle eksemplet for meg er hovedstadsprosessen i Oslo, der mange tenker at beslutningene har gått for fort og at det har vært for lite medvirkning og man har problemer med å forstå gevinsten av en så omfattende endring. Jeg håper deltakerne har fått denne boken. Anbefales!

\section{Ewa Ness}

Psykiatrisk divisjon

Oslo universitetssykehus

\section{Godt om hukommelse}

\author{
Karlsen PJ. \\ Hva er hukommelse \\ 155 s. Oslo: Universitetsforlaget, 2008. \\ Pris NOK 149 \\ ISBN 978-82-15-01252-0
}

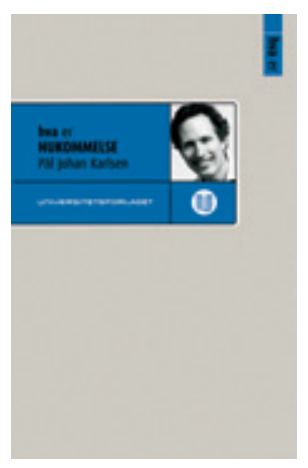

Det er ingen lett oppgave forfatteren har tatt på seg når han på 150 små sider skal gjøre klart for leseren hva hukommelse er. La det straks være sagt at Pål Johan Karlsen har gjort en god jobb. Her er det intet irrelevant stoff. Fremstil-

lingen er velskrevet, og den «du» som forfatteren gjennomgående henvender seg til, viser seg etter hvert å være en universitetsstudent. De mange illustrerende eksempler forfatteren bruker, er da også hyppig hentet fra dette miljøet. En del tekniske termer og akademiske formuleringer vil vel ikke falle tungt for slike lesere. Men i hovedtrekk er fremstillingen språklig grei, slik at det er få lesergrupper som vil ha vansker med å følge med.

Etter en 15 siders innledning, der forfatteren søker å plassere hukommelsespsykologien, følger seks kapitler. Det første tar opp spørsmålet om hva et minne er, og det fremgår at ordet «minne» kan vise hen til forskjellige saksforhold. Kapittel 2 trekker opp brede historiske linjer og gir leseren innblikk i noen av de metoder som er blitt brukt for å utforske spørsmål som har med hukommelse å gjøre. Tredje kapittel omhandler hukommelsestap, kapittel 4 ulike typer hukommelse, kapittel 5 glemsel og i det siste, sjette kapitlet er temaet hvordan man husker.

Hvert av de tematiske kapitlene gir ved flere konkrete eksempler leseren en god innføring i de saksforhold som behandles. 